\title{
Jenkins v. Missouri: School Choice as a Method for Desegregating an Inner-City School District
}

\author{
Deborah E. Beck $\uparrow$
}

This Casenote describes the difficulties faced by school districts striving to provide desegregated education for children living in predominantly minority inner-city areas. In particular, it examines the challenge confronting the Kansas City Metropolitan School District (KCMSD) and suggests that educational vouchers would be a legally appropriate remedy. In Jenkins v. Missouri, originally filed on behalf of black KCMSD schoolchildren in 1977, the district court found that the KCMSD and the State of Missouri had created a dual, or segregated, school system and ordered the defendants to dismantle that system. To date, however, none of the court-ordered remedies, including a voluntary interdistrict transfer plan and a costly magnet school program, has succeeded in desegregating the $K C M S D$. The author argues that an alternative remedy-by which the KCMSD would provide tuition vouchers to black children to enable them to attend private schools in the district-is constitutional and worthy of consideration.

\section{INTRODUCTION}

Almost forty years after Brown v. Board of Education ${ }^{1}$ mandated school desegregation, thousands of inner-city children continue to attend identifiably one-race schools. For these children, the right to a desegregated education has hittle meaning. They remain trapped in segregated schools that are generally regarded as inferior to their predominantly white counterparts. ${ }^{2}$

The Kansas City Metropolitan School District (KCMSD) is a predominantly black, ${ }^{3}$ inner-city district surrounded by eleven predomi-

$\dagger$ B.A. 1972, University of San Francisco; J.D. 1992, Boalt Hall School of Law, University of California, Berkeley. The author would like to thank Professors John Coons and Steven Sugarman for their encouragement and assistance.

1. 349 U.S. 294 (1955) (Brown II); Brown v. Board of Educ., 347 U.S. 483 (1954) (Brown $I$ ).

2. See Jenkins v. Missouri, 639 F. Supp. 19, 24 (W.D. Mo. 1985), aff'd as modified, 807 F.2d 657 (8th Cir. 1986), cert. denied, 484 U.S. 816 (1987) ("Segregation has caused a system wide reduction in student achievement in the schools of the KCMSD.").

3. Only $26 \%$ of KCMSD students are white. Patricia King, When Desegregation Backfires, NewsweEk, July 31, 1989, at 56. 
nantly white, suburban districts. Although the KCMSD has been operating since 1985 under a court-ordered desegregation plan, ${ }^{4}$ it has not yet been released froin judicial oversight. In fact, the percentage of black students in the district's schools lias increased slightly since the plan was impleinented. ${ }^{5}$

The KCMSD faces a difficult challenge: how to provide a desegregated education to children who reside in its largely black inner-city area. Seeıningly insurmountable constitutional, political, and practical probleins stand in the way. An intradistrict plan involving only public schools will not achieve desegregation because, in a district that is $74 \%$ minority, there simply are not enough white children to enable the district to attain the $60 / 40$ ininority to nonminority ratio ordered by the court. An interdistrict busing plan would at least achieve numerical desegregation, but such a plan cannot be implemented in Kansas City. In Milliken v. Bradley, ${ }^{6}$ the Supreme Court prohibited imposition of an interdistrict plan absent a finding that the surrounding districts contributed to or exacerbated segregation in the complaining district. ${ }^{7} \mathrm{~A}$ federal court of appeals exonerated Kansas City's suburban school districts in 1987.8

Although no one questions that the district court has atteinpted in good faith to erase the vestiges of the State's prior dual school systein, it has becoine apparent that the current reinedial plan offers no proinise of effecting desegregation. This Casenote outlines the legal inplications of

4. Jenkins v. Missouri, 593 F. Supp. 1485 (W.D. Mo. 1984).

5. Plaintiff' Statement of Facts and Legal Issues at 4, Rivarde v. Missouri, No. 89-0671-CVW-8 (W.D. Mo. filed July 14, 1989), aff'd, 930 F.2d 641 (8th Cir. 1991) (citing 1988 Report to the Community by the School District of Kansas City, Missouri). Between late 1987 and early 1990, enrollment fell from 35,429 to 34,348 students; during the same period the proportion of minority students rose from 74.1\% to 74.9\%. Kansas CiTY STAR, Apr. 19, 1990, at A16. At present, it appears that white flight has subsided; indeed, the percentage of white pupils in the district's schools rose a half point during the 1991-92 school year, to 25.8\%. Dennis Farney, Can Big Money Fix Urban School Systems?, WALI ST. J., Jan. 7, 1992, at A1, A4 (Eastern ed.). That percentage remains far below the $40 \%$ goal set by Judge Clark, however. Id.

6. 418 U.S. 717 (1974) (Milliken I).

7. Id. at 752 .

8. Jenkins v. Missouri, 807 F.2d 657, 674 \& n.20 (8th Cir. 1986), cert. denied, 484 U.S. 816 (1987) (district court finding "that no [suburban school district] had committed any constitutional violation that had interdistrict segregative effect," following Milliken, poses "an insuperable barrier to granting interdistrict relief"). Thus, although "[a] voluntary interdistrict program has great potential for improving the racial balance in the Kansas City area . . . such a program cannot be mandatorily imposed." Id. at 683 n.30.

Nevertheless, the Eighth Circuit recently ordered renewed exploration of the issue of voluntary interdistrict transfer plans. Jenkins v. Missouri, 981 F.2d 1008, 1015 (8th Cir. 1992). In 1991 a representative of the Jenkins class personally negotiated two such plans with the suburban school districts, which subsequently withdrew their agreement to participate in the face of strong objections by the State, the KCMSD, and the American Federation of Teachers. Noting those parties' strong objections to the terms of the negotiated plans, the court warned that "KCMSD and the State, as constitutional violators, are subject to an order to participate in such plans even though they may not have participated in the settlement discussions or agreed to the settlement." Id. at 1013. 
an innovative solution that a subset of the Jenkins plaintiffs has proposed to the court.

A class action lawsuit filed on behalf of all similarly situated plaintiffs by Quintin Jude Rivarde, a fifth grader, proposes a plan that would incorporate private and parochial schools in the reinedy. ${ }^{9}$ The Rivarde complaint asks the KCMSD to provide tuition vouchers to all black children who are not receiving the desegregated education to which they are entitled. ${ }^{10}$ Those vouchers could be redeemed according to parental choice at any of over fifty identified private schools ${ }^{11}$ inside the geographic limits of the KCMSD and would enable a number of black children who could not otherwise afford it to attend private schools. ${ }^{12}$ Under the Rivarde plan, over fifty private schools, which are largely white, have agreed to accept any black child whose parents can pay the schools' modest tuition. ${ }^{13}$

Implementation of a voucher prograin in Kansas City can help solve the Jenkins court's dilemma by giving many black children immediate access to desegregated education in the schools of their choice. ${ }^{14}$ The

9. See Rivarde v. Missouri, No. 89-0671-CV-W-8 (W.D. Mo. filed July 14, 1989). Although Rivarde began as a separate lawsuit, on April 16, 1991 the Eighth Circuit, relying upon considerations of judicial economy, held that the students could not bring a new and independent action raising claims based on the desegregation order issued in the pending class action but, instead, would be required to intervene in Jenkins. Rivarde v. Missouri, 930 F.2d 641 (8th Cir. 1991). This procedural development does not change the Rivarde plaintiff's claim to immediate relief under the Fourteenth Amendment, and the plaintiffs are preparing to intervene.

10. Education vouchers are certificates that the government would distribute to parents of school-age children to pay tuition at the public or private schools of their choice. The participating schools would redeem these vouchers for cash from the state or school district treasury. The government would provide certificates rather than cash to ensure that the funds are spent for education. 1249).

11. See Brief of Appellant at 5, Rivarde v. Missouri, 930 F.2d 641 (8th Cir. 1991) (No. 90-

12. It is important to emphasize here that the Rivarde voucher plan is a very limited one; it would include only black schoolchildren in the KCMSD who have been denied a desegregated education. A theoretical discussion of the myriad of choice and voucher programs which have been suggested in a wide variety of other contexts is far beyond the scope of this Casenote. Proponents of the Rivarde plan are not-as the plan's critics argue-advocating the destruction of the American public school system; they are simply suggesting that a limited voucher program in Kansas City would serve the court's stated interest in effecting desegregation.

13. The private schools, who volunteered to participate in the remedy, believe that both transfer and current students will benefit from increased diversity. Admissions standards for transfer students would be determined according to the same rules negotiated with the suburban public schools when the voluntary interdistrict transfer plan was created. These admissions standards provide that the private schools would accept students on a first-come, first-served basis, and could not refuse to enroll any child unless he or she had a history of serious disciplinary problems.

14. When the Rivarde plaintiffs filed their complaint, over 4000 private school slots had been identified. See Brief of Appellant at 14, Rivarde v. Missouri, 930 F.2d 641 (8th Cir. 1991) (No. 90 1249). At present, there are not enough private school slots available to accommodate every black child in the KCMSD, should every child choose to participate in the program. There are enough places currently available, however, to contribute significantly to the desegregation effort. 
voucher program is also likely to assist the desegregation effort in the public schools. Because a number of black children would leave the KCMSD for private schools, the proportion of black to white students in the KCMSD would decrease. Those black students who remain in the public schools would thus liave a greater likelihood of receiving a desegregated education. ${ }^{15}$

Althougli the plan's detractors argue otlierwise, there is no legal reason not to implement tlie Rivarde remedy. It is "a plan that promises realistically to work, and promises realistically to work now."16 The Establishment Clause does not prohibit the Rivarde approach, ${ }^{17}$ and the program does not undermine the desegregation plan ordered by the Jenkins court. ${ }^{18}$

This Casenote examines the novel remedy sought by the Rivarde plaintiffs and concludes that it should be implemented. The Rivarde remedy is a feasible one; indeed, it may be the only practical way to provide a desegregated education to children in predominantly black inner-city school districts when surrounding white suburbs have not been implicated in any constitutional violations.

Part I of this Casenote describes the Jenkins case and summarizes the current state of the law by briefly sketcling the chronology of school desegregation cases from Brown to the present. Relating these cases to the factual situations of Jenkins and Rivarde, the Casenote argues that the district court can and should order the KCMSD to implement a feasible solution that will provide immediate relief. Part II considers the feasibility of implementing a parental choice program in Kansas City; this Part concludes that a voucher program will greatly assist Kansas City's desegregation efforts. Part III outlines corollary legal issues. The Casenote concludes that the current desegregation plan has failed many of the Jenkins plaintiffs and, while important questions remain, the Rivarde remedy is the court's best option for solving the KCMSD's continuing problem of school segregation.

15. Implementation of the plan would help to desegregate the public schools. Approximately 36,000 students are enrolled in KCMSD public schools; of those, 73.6\%-or approximately 26,496 -belong to minority groups. See Jordan, infra note 38 . If 4000 black students choose to leave the district for private schools, the proportion of minority students in the district will immediately drop to $70 \%$, even if white students fail to replace the departing black students. And if such measurable progress towards desegregation encourages 4000 white students to enroll in KCMSD magnet schools, the proportion of minority students will drop further, to $62 \%$. This would put the district remarkably close to the $60 / 40$ ratio set by the district court.

16. Green v. County Sch. Bd., 391 U.S. 430, 439 (1968).

17. See infra notes $158-81$ and accompanying text.

18. See infra notes $189-92$ and accompanying text. 


\section{I}

Chronology: JeNkins $v$. Missouri and the MaNdATE OF THE SCHOOL DESEgREgation CASES

\section{A. A Brief History of Jenkins}

Missouri mandated racially segregated schools until Brown outlawed that practice in 1954. In Jenkins v. Missouri, ${ }^{19}$ originally filed in $1977,{ }^{20}$ plaintiff black schoolchildren alleged that after 1954, the State not only failed to take affirmative steps to eliminate the vestiges of its prior dual school system but actually perpetuated that system through unfair housing practices, discriminatory relocation of blacks displaced by highway construction projects and urban development, and support of racially-identifiable interdistrict vocational and special education prograins. ${ }^{21}$

The plaintiffs alleged that the KCMSD had acted with a similar intent to discriminate, and claimed that, after 1954, the KCMSD adopted "meffective poicies to change the segregative patterns that were developed or developing."22 The plaintiffs conceded, however, that the failure of the desegregation attempt was to some extent due to factors beyond the KCMSD's control, such as an influx of blacks from southern and border states, white flight, and housing policies of other agencies. ${ }^{23}$

The KCMSD cross-claimed agaimst the State, alleging that because the State had ignored its constitutional obligation to dismantle its prior dual school system, it was primarily hable for contimuing segregation in the district. ${ }^{24}$

In the district court, the plaintiffs' claim against the KCMSD and the State prevailed. In addition, the KCMSD succeeded in its crossclaim against the State. ${ }^{25}$ In a finding of fact, the trial court pointed out that the KCMSD was predominantly white until 1970 and could have achieved racial balance in its schools until that year. "Instead, the District chose to operate some coinpletely segregated schools and soine integrated ones. ... [This] chosen path was ineffective in integrating its school system." 26 The court found that, "having created a dual system, the State and the KCMSD had and continue to have an obligation to disestablish that system."27

19. 593 F. Supp. 1485 (W.D. Mo. 1984).

20. Jenkins v. Missouri, 807 F.2d 657, 661 (8th Cir. 1986), cert. denied, 484 U.S. 816 (1987).

21. Jenkins, 593 F. Supp. at 1488.

22. Id.

23. Id.

24. Id. at $1488-89$.

25. Id. at 1488.

26. Id. at 1492 . By 1974,39 of the district's schools were more than $90 \%$ black and $80 \%$ of the district's black students attended schools that were more than $90 \%$ black. Id. at 1492-93.

27. Id. at 1504. 
In 1985 the district court approved a remedial plan and imposed a tax increase to pay for it; ${ }^{28}$ that tax mcrease was effectively upheld by the Supreme Court in $1990 .{ }^{29}$ The initial remedial plan required at least $30 \%$ minority enrollment in each of the district's schools. ${ }^{30}$ It also created a voluntary interdistrict transfer plan to encourage black students to attend public schools in the suburbs and white students to transfer to the KCMSD. ${ }^{31}$ In a further attempt to attract white students to the innercity schools, the plan mandated major capital improvements for existing schools and an ambitious magnet school program. ${ }^{32}$ Magnet school minority to nonminority ratios, originally set at $50 / 50,{ }^{33}$ were later adjusted to $60 / 40 . .^{34}$

Although estiniates of the plan's eventual cost approach $\$ 1.2$ bilhon, ${ }^{35}$ none of the ordered remedies has succeeded in desegregating the KCMSD to date. Although the district balanced a few schools at the required $60 / 40$ ratio by busing a limited nuinber of black children to the remaining white neighborhoods in the district, ${ }^{36}$ the nuinber of racially balanced schools is necessarily limited by a population that is now $75 \%$ minority. ${ }^{37}$ As a practical matter, most students in the KCMSD do not

28. Jenkins v. Missouri, 639 F. Supp. 19, 36 (W.D. Mo. 1985), aff'd as modified, 807 F.2d 657 (8th Cir. 1986), cert. denied, 484 U.S. 816 (1987). For a more detailed explanation of Judge Clark's unprecedented tax increase, see infra note 56.

29. Jenkins v. Missouri, 495 U.S. 33 (1990); see infra note 56.

30. Jenkins, 639 F. Supp. at 36.

31. The court had originally ordered the state to pay the transportation and tuition costs of blaek KCMSD students who wished to be educated in desegregated schools in other districts in the Kansas City metropolitan area. See id. at 39.

32. Id. at 34-35.

33. Id. at 55 .

34. Ronika Newton et al.'s Motion to Modify Long Range Magnet School Plan at 3, Jenkins v. Missouri, No. 77-0420-CV-W-4, 1989 WL 299246 (W.D. Mo. Jan. 3, 1989) (citing KCMSD Long Range Magnet School Plan at 18).

35. Farney, supra note 5, at A-1, A-4. By contrast, it is estimated that the Rivarde remedy will cost the state one third as much as it currently spends per child. The KCMSD, with assistance from the state, currently spends approximately $\$ 6000$ per child per year. King, supra note 3, at 56; Richard Nadler \& Tom Donelson, Affirmative Reaction, NAT'L REV., Sept. 15, 1989, at 29. The approximate cost per child at the private and parochial schools identified by the Rivarde petition averages less than $\$ 2000$ per year for elementary schools, and less than $\$ 3000$ per year for high schools. See Complaint for Further Necessary and Proper Relief Based on Declaratory Judgment at 12-18, Rivarde v. Missouri, No. 89-0671-CV-W-8 (W.D. Mo. filed July 14, 1989).

36. John E. Coons, Parable from the Prairie, First Things, Apr. 1990, at 1.

37. During the 1991-92 school year, $74.2 \%$ of KCMSD students belonged to minority groups. Although that figure represents a one-half percent decrease from the previous school year, the percentage of minority students over the years has not changed substantially. See Desegregation Monitoring Comm., Report of the Desegregation Monitoring Committec 7 (Aug. 20, 1992) (unpublished manuscript, on file with author). During the 1985-86 school year, when the desegregation plan went into effect, $73.6 \%$ of KCMSD students belonged to minority groups. See Dennis Kelly \& Anita Manning, Examining the Ability to Desegregate, USA TODAY, Apr. 2, 1992, at 1D; Correction, USA TODAY, Apr. 6, 1992 (correcting minority enrollment figures in April 2, 1992 article). 
have access to desegregated schools. ${ }^{38}$

The voluntary interdistrict transfer plan has not helped the desegregation effort, because almost all of the suburban public schools have effectively refused to accept black students from the KCMSD. Although approximately 10,000 black families expressed interest during the plan's first twenty-two inontlis, ${ }^{39}$ in the seven years since tlie plan was implemented only ten KCMSD students have transferred to the suburbs. ${ }^{40}$ This is unfortunate because desegregating the KCMSD without the cooperation of the suburban school districts appears higlily unlikely. ${ }^{41}$

The key aspect of tlie desegregation plan-a higlily touted ${ }^{42}$ and extraordinarily expensive magnet school program ${ }^{43}$-has also failed to lure a significant number of white students to the KCMSD. Althougl more than $\$ 500$ million lias been spent to date on construction of new magnet schools and remodeling of existing scliools, ${ }^{44}$ tlie KCMSD has

38. The Desegregation Monitoring Committee concluded that "[p]rogress is far short of expectations." Desegregation Monitoring Comm., supra note 37, at 7. The plan has succeeded in reducing the number of elementary and secondary schools with more than $90 \%$ minority enrollment from 25 in 1987-88 to 14 in 1991-92. The magnet school program (56 of the district's 78 elementary, middle, and high schools are magnets) has produced mixed results. The number of minority students has decreased in 33 of the magnet schools but mcreased in 22 of them; the number of minority students in one middle school remained the same. Id. at 8 . The Monitoring Committee's report concluded that these minor gains are "clearly inadequate in relationship to the dollars expended." Id. at 7.

But KCMSD officials continue to express optimism that the overall percentage of minority students in the district will drop before the decade is over. District officials also contend that the desegregation plan has at least stopped white flight. See Mary Jordan, Kansas City's Costly Integration Strategy: Results Mixed in \$1.2 Billion School Plan, WASH. PosT, Apr. 11, 1992, at A1; Elizabeth Levitan Spaid, 'Magnets' Attract in Kansas City, Christ1AN ScI. Monrror, June 15, 1992, at 12.

39. JoAnn G. Goedert, Case Comment, Jenkins v. Missouri: The Future of Interdistrict School Desegregation, 76 Geo. L.J. 1867, 1915 n.271 (1988).

40. Brief of Appellants Kalima Jenkins et al. at 4, Jenkins v. Missouri, No. 92-1278WMKC (8th Cir. brief filed Feb. 19, 1992) (explaining that the only black students to participate in a voluntary interdistrict plan since the initial order was issued were ten students who enrolled in Missouri City in 1991 and 1992); see also Brief of Appellant at 14, Rivarde v. Missouri, 930 F.2d 641 (8th Cir. 1991) (No. 90-1249) ("No public schools outside KCMSD have been or are presently willing to accept transfers."); Goedert, supra note 39, at $1915 \mathrm{n.271}$ ("[N]one of the 11 [suburban school districts] agreed to accept black transfer students for the KCMSD.").

41. The problem was recognized by the court even as it created the voluntary interdistrict transfer plan in 1985. See Jenkins v. Missouri, 639 F. Supp. 19, 38 (W.D. Mo. 1985), aff'd as modified, 807 F.2d 657 (8th Cir. 1986), cert. denied, 484 U.S 816 (1987) ("To accomplish desegregation within the boundary lines of a school district whose enrollment remains $68.3 \%$ black is a difficult task.").

42. See King, supra note 3 , at 56.

43. For example, the new Central High School, one of the most expensive magnet schools, will cost an estimated $\$ 32$ million, twice as much as the "typical" high school. James Kilpatrick, Kansas City Schools in Wonderland, BATON Rouge ST. Times, Aug. 22, 1989; see also Farney, supra note 5 , at A1. In addition to 1000 computers and courses in classical Greek, its amenities include an indoor track one-tenth of a mile long, a 50-meter indoor swimming pool, a weight room, handball courts, and a room for the exclusive use of gymnasts. Kilpatrick, supra.

44. See Kelly \& Manning, supra note 37. 
attracted fewer than 750 new white students, less than $3 \%$ of the district's total enrollment. ${ }^{45}$ Numerically, the district is in about the same position it occupied before the desegregation plan was implemented. ${ }^{46}$

Although the plan thus far has failed to effect desegregation, black parents are hopeful that the magnet school program might at least improve the quality of their children's education. ${ }^{47}$ Iromically, the court's preoccupation with the legal requirement of numerically desegregated schools has caused it to lose sight of a policy concern desegregation was designed to address-improvement of educational opportunity for minority students. ${ }^{48}$

For example, until recently, more than 3000 black students languished on magnet school waiting lists while available maguet schools sat half-empty waitimg for the requisite number of white students to enroll. ${ }^{49}$ The district court at first refused to allow each maguet school immediately to fill $60 \%$ of available seats with black children, even if no white students materialized to fill the remaining seats. ${ }^{50}$ Instead, six black children were admitted with every four white children who enrolled, and not before. ${ }^{51}$ Thus, if only 100 white students chose to enroll in a magnet school designed to accommodate 1000 students, only 150 black students would be admitted. The remaining 750 spaces would be held open until more white students appeared.

This strict adherence to numerical ratios led some frnstrated black parents to register their children as white, so that they could enroll in the

45. See Desegregation Monitoring Comm., supra note 37, at 9.

46. Missouri Governor Mel Carnahan, in his first state of the state address, recommended ending the costly federal desegregation cases in Kansas City and St. Louis. He said that he would ask the state attorney general to petition to end the case and might appoint a neutral party to negotiate a settlement so that court oversight of Kansas City schools might end. John Racine, State of the State: Missouri, BOND BUYER, Jan. 20, 1993, at 32. As the Eighth Circuit has explained, the state, through its legislative and admimistrative bodies, has the authority to establish an interdistrict plan if it chooses, and may require suburban districts to accept minority transfer students from KCMSD. The legislature could establish such a plan and implement it without the constraints that limit the courts. See Jenkins v. Missouri, 981 F.2d 1009, 1015 (8th Cir. 1992) (rccommending "affirmative efforts" to push voluntary interdistrict transfer plans to completion). The legislature could, of course, also establish a voucher program like the one the Rivarde plaintiffs suggest.

47. Expected improvements in student achievement have not occurred except at the K-2 level. See Desegregation Monitoring Comm., supra note 37, at 19. Noting that "the desegregation plan requires both desegregated schools and improved educational achievement," the Committee concluded that "[i]mproved educational achievement has not been accomplished at an acceptable rate." Id.

48. See King, supra note 3, at 56 ("Arthur Benson, who represents students in the .. desegregation suit, stresses that the court's focus is integrated education, not quality education.").

49. Id.; see also Arlynn L. Presser, Broken Dreams, A.B.A. J., May 1991, at 60, 64 ("[E]mpty seats were required to remain so-waiting for non-existent white students while blacks were turned away.").

50. See Ronika Newton et al.'s Motion to Modify Long Range Magnet School Plan at 3-4, No. 77-0420-CV-W-4, Jenkins v. Missouri, 1989 WL 299246 (W.D. Mo. Jan 3,1989).

51. Id. at 3 (citing Nov. 12, 1986 order approving KCMSD Long Range Magnet School Plan). 
magnet schools. ${ }^{52}$ Other parents are appealing Judge Clark's application of the $60 / 40$ ratio. $^{53}$ Judge Clark eventually ruled that until the appeal is decided, minority students may fill all available magnet school seats. ${ }^{54}$ Thus, the situation of some children has improved, at least temporarily. But most are still not receiving the desegregated education to which they are entitled. And despite some indications of improvement, most of KCMSD's schools remain troubled; the district-wide dropout rate for junior and semor high school students exceeds $40 \%$, and the daily absentee rate is $30 \% 55$

Fimally, one strictly economic factor indicates that Kansas City may not be able to afford to wait for tlie current plan to succeed. Although the plan has been funded by local tax mcreases that the court ordered the district to levy, the school board may be unwilling to implement additional increases to keep the plan afloat. ${ }^{56}$ Altlough the Supreme Court effectively upheld Judge Clark's tax imcrease when it ruled that the lower court could require the school board to levy adequate property taxes, the scliool board, recognizing the political ramifications of sucli recommendations, may oppose further increases. ${ }^{57}$ As Julia $\mathrm{H}$. Hill, president of

52. See J. Duncan Moore Jr., Black Parents Registering Pupils as White, S.F. Chron., Sept. 4, 1989, at A1; Nadler \& Donelson, supra note 35, at 28, 29; Presser, supra note 49, at 64.

53. See Ronika Newton et al.'s Motion to Modify Long Range Magnet School Plan at 3-4, Jeukins v. Missouri, No. 77-0420-CV-W-4, 1989 WL 299246 (W.D. Mo. Jan. 3, 1989).

54. Julia H. Hill, Holding Fast, A.B.A. J., Sept. 1991, at 70, 72.

55. Farney, supra note 5, at A4.

56. Judge Clark's $1.5 \%$ income tax surcharge, imposed in 1985 on all Kansas City employees, was struck down by the Eighth Circuit in Jenkins v. Missouri, 855 F.2d 1295, 1315-16 (8th Cir. 1988), aff'd in part, rev'd in part, 495 U.S. 33 (1990). In Missouri v. Jenkins, 495 U.S. 33 (1990), the Supreme Court ruled that the district court order doubling property taxes to ensure funding of the desegregation plan violated principles of federal/state comity where the court had another alternative. In this case, the district court "could have authorized or required the KCMSD to levy property taxes at a rate adequate to fund the desegregation remedy and could have enjoined the operation of state laws that would have prevented KCMSD from exercising" that power. Id. at 5051; see also id. at 38-39 (describing the Hancock Amendment to the Missouri Constitution, which limits property tax rates). The Court refused to consider whether the remedial order itself was excessive, since that issue was outside the Court's limited grant of certiorari. Id. at 53.

57. Jenkins, 495 U.S. at 50-52. The politics of voucher programs are complicated and outside the scope of this Casenote. It does seem clear, however, that the concept provokes strong responses from elements of the current educational system. See Chester E. Finn, Jr., The Choice Backlash, EDUC. FREEDOM, Spring-Summer 1990, at 10, 13-14 ("Choice augurs a rearrangement of power and authority relationships in American education, and the farther-reaching and more comprehensive the choice policy, the more total the reallocation of power.").

Proponents have noted that, as a general matter, the idea of school choice is widely supported by "an astonishing coalition" of people-by "the liberal Brookings Institution and the conservative Heritage Foundation, by The Nation and The National Review, by libertarians, Roman Catholics, Afrocentrists, radieals, much of the business elite ... minorities ... and by Americans in general." John Leo, School Reform's Best Choice, U.S. News \& WorLD REP., Jan. 14, 1991, at 17. Indeed, although KCMSD teachers and administrators publicly oppose the plan, a number of them have privately admitted that the Rivarde solution is in the best interests of the children. See Coons, supra note 36, at 2; John E. Coons, For Free Educational Choice, Educ. FrEeDoM, Fall-Winter 1989-90, at 26,26 . 
KCMSD's board, noted:

It is far from politically expedient for the board of education to support tax mcreases to fund desegregation; we are elected officials. As the desegregation remedy developed, we went to the voters in 1986 and 1987 witl four separate attempts to pass bond issues on tax levy increases. All of those funding proposals failed, as has every levy increase proposal since 1969, when the district became predominantly minority. ${ }^{58}$

Local voters do not favor furtlier desegregation-related tax increases. Furthermore, the State may be ordered to refund part of the nearly $\$ 34$ million in taxes that state taxpayers paid "under protest" from 1987 through $1989 .{ }^{59}$ Since the state and the district share financial responsibility for the desegregation plan, a refund by the State will exacerbate the district's econoinic problems.

\section{B. "With All Deliberate Speed"}

School desegregation doctrime lias by necessity evolved on both legal and political levels. ${ }^{60}$ Recognizing that no single plan is appropriate for all cominurities, the Supreine Court has been mindful of the coinplexities imvolved im dismantling dual school systeins. Because it was reluctant to mvade the domain of local autlorities, the Court at first merely issued guidelines for the lower courts so that trial judges and school boards could retain some discretion in fashioning relnedies appropriate to their communities. As time passed, however, and communities refused to implement feasible desegregation plans, the Court became more deterimned and the language of its opinions became more commanding. Althougl the Court has taken a somewhat tortured path over the last four decades, it eventually arrived at a relatively clear mandate: the Fourteentl Amendment requires "the greatest possible degree of actual desegregation."61 Such actual desegregation ${ }^{62}$ 1nust be impleinented

58. Hill, supra note 54 , at 71 .

59. See KanSas CitY STAR, Apr. 19, 1990, at A-16.

60. For an analysis of the interplay of legalism and politics, see DAV1D L. K1RP, JUST Schools: The IdEA of RACIAL EQUALITY IN AMERICAN EdUCATION 50-71 (1982) ("The effort to shape race and schooling policy does not embody a coherent strategy to effectuate unitary norms. It reflects instead a continuing struggle to identify resolutions at once politically palatable, educationally sensible, and constitutionally permissible . . . Id. at 51); see also William A. Fletcher, The Discretionary Constitution: Institutional Remedies and Judicial Legitimacy, 91 Y ALE L.J. 635 (1982) (arguing that the remedial discretion of a trial court in institutional suits is political and therefore must be regarded as presumptively illegitimate and that the presumption may be overcome when the political bodies that should ordinarily exercise discretion are seriously in default).

61. Swann v. Charlotte-Mecklenburg Bd. of Educ., 402 U.S. 1, 26 (1971); Davis v. Board of Sch. Comm'rs, 402 U.S. 33, 37 (1971).

62. The Court measures actual desegregation by numbers. See, e.g., Swann, 402 U.S. at 25 (observing that, although the number of students in every school does not always have to reflect the 
"with a plan that promises realistically to work . . now."63

In Brown v. Board of Education, ${ }^{64}$ the Supreme Court articulated the basic principle of equal educational opportunity, holding that segregated school systems violate the equal protection guarantee of the Fourteenth Amendment. In a much-quoted passage, the Court explained the rationale underlying its holding:

Segregation of white and colored children in public schools has a detrimental effect upon the colored children. The . . . policy of separating the races is usually interpreted as denoting tlie inferiority of tlie negro group. A sense of inferiority affects the motivation of a child to learn. Segregation ... tlierefore, has a tendency to [retard] the educational and mental development of negro children and to deprive tliem of some of the benefits they would receive in a racial[ly] integrated school system. ${ }^{65}$

The Court did not order an immediate remedy for tlie segregation probleins it described. Instead, it decreed that local school authorities should dismantle segregated scliool systems "witl all deliberate speed."66

Several scholars have criticized the Brown Court's tentative approach. ${ }^{67}$ The Court's initial hesitancy was understandable given the

racial composition of the school system as a whole, the use of racial ratios as a "starting point" is within the court's equitable discretion.); United States v. Montgomery County Bd. of Educ., 395 U.S. 225 (1969) (upholding a district court order mandating desegregation of faculty and staff according to specific ratios).

63. Grecn v. County Sch. Bd., 391 U.S. 430, 439 (1968) (rejecting a "freedom of choice" plan when alternatives promised speedier and nore effective conversion to a unitary system).

64. 349 U.S. 294 (1955) (Brown II); Brown v. Board of Educ., 347 U.S. 483 (1954) (Brown I).

65. Brown I, 347 U.S. at 494 (quoting a finding by a court in the Kansas case). The Brown Court's reliance on social science doctrine has been criticized. For that rcason, few subsequent cases mention the stigma caused by segregation. Nevertheless, remedying this "stigmatizing injnry" has been a goal of the Court since it decided Brown. See Board of Educ. v. Dowell, 498 U.S. 237, 251-52 (1991) (Marshal1, J., dissenting).

66. Brown II, 349 U.S. at 301. As a member of the Solicitor General's Office from 1944-1961, Philip Elman, former law clerk to Felix Frankfurter, takes credit for developing the idea of "all deliberate speed" and admits that he "was on very shaky legal ground" in doing so. See Philip Elman, The Solicitor General's Office, Justice Frankfurter, and Civil Rights Litigation, 1946-1960: An Oral History, 100 HARv. L. REv. 817, 829 (1987) (interview with Norman Silber):

It was entirely unprimcipled, it was just plain wrong as a matter of constitutional law, to suggest that someone whose personal constitutional rights were being violated should be denied relief. ... That's what we were arguing, even though the Suprenie Court had held again and again that constitutional rights are personal, that if an individual's constitutional rights are being violated, he is entitled to ininiediate relief. As a matter of constitutional principle, what we were arguing . . . was simply indefensible.

Id. at 827-28. The "all deliberate speed" formula was developed for purely tactical reasons. "[T] is why I made this 'indefensible' argument . . . . I was simply counting votes on the Supreme Court. I was trying to come up with a realistic formula that would win the case . . . It was as siniple as that." Id. at 829.

67. See, e.g., Lino A. Graglia, Disaster By DeCreE 33-37 (1976) (arguing that the Court's refusal to order immediate relief enormously complicated and confused the issues); Louis Lusky, Racial Discrimination and the Federal Law: A Problem in Nullification, 63 Colum. L. REv. 1163, 1163-64 (1963) (noting the "difference between waiting for the establishment of a new right and 
complexities of effecting a nationwide transition to a desegregated school systein, but its timid approach spawned a number of local scheines to avoid the constitutional inandate. The Court adopted a very lenient, wait-and-see attitude over the next decade, responding only to the most egregious atteinpts to perpetuate segregation. ${ }^{68}$

As a result of this lemient attitude, ten years after Brown, $98.8 \%$ of black children in eleven southern states continued to attend segregated schools; only $1.2 \%$ attended schools with whitc children. ${ }^{69}$ When the Court realized that no appreciable progress towards integration had been made, it began to express its impatience with school boards that purposefully impeded desegregation. Finally, in Griffin v. County School Board, ${ }^{70}$ the Court announced that " $[t]$ he time for mere "deliberate speed' ha[d] run out ...."71 Noting that the original suit in Griffin had been filed thirteen years earlier, the Court scolded, "[t]he original plaintiffs have doubtless all passed high school age. There has been entirely too much deliberation and not enough speed in enforcing the constitutional riglits which ... had been derned . . Negro children."72 The Court ruled that "relief needs to be quick and effective"73 to prevent further racial discrimination.

\section{The "Affirmative Duty" of School Boards to Eliminate Racial Discrimination "Root and Branch"}

The Court used still more urgent language in Green v. County School Board, ${ }^{74}$ a unanimous decision invalidating a shain "freedoin of choice" plan. The Court found that the "freedoin of choice" plan adopted by the New Kent County, Virginia school board was an insufficient step to effect the Brown-mandated transition to a unitary, ${ }^{75}$ nonracial school systein and could not realistically be expected to provide relief since no

waiting for [the enjoyment of that right] after it has been established," and arguing that federal rights, once established, must be immediately enforceable).

68. See, e.g., Goss v. Board of Educ., 373 U.S. 683 (1963) (invalidating a "freedom of choice" plan where the inevitable effect of such "freedom of choice" was the perpetuation of school segregation); Cooper v. Aaron, 358 U.S. 1, 15 (1958) (conditions directly traceable to actions of state officials are not grounds for additional delay).

69. U.S. COMM'N ON CIVIL RIghtS, TwentY YEARS AFTER BRown 48 (1977).

70. 377 U.S. 218 (1964) (closing public schools to evade desegregation order while contributing to the support of private segregated white schools that took their place denied black students' rights to equal protection).

71. Id. at 234 .

72. Id. at 229.

73. Id. at 232 .

74. 391 U.S. 430 (1968).

75. The Court has never expressly defined "unitary." See Tracy E. Sivitz, Note, Eliminating the Continuing Effects of the Violation: Compensatory Education as a Remedy for Unlawful School Segregation, 97 YALE L.J. 1173, 1190 (1988) (observing that the legal significance of a unitary status finding has not been clearly elaborated by the Court); Note, Allocating the Burden of Proof After a Finding of Unitariness in School Desegregation Litigation, 100 HARv. L. REV. 653, 662 (1987) ("The 
white student had "chosen" to enroll at the black school and $85 \%$ of the black students continued to attend the all-black school. ${ }^{76}$ The Court ordered the school board to "fashion steps which promise realistically to convert promptly to a system without a 'white' school and a 'Negro' school, but just schools." 77

Green is miportant for two reasons. First, it conveys a clear sense of urgency. Second, it expressly imposes an "affirmative duty" on school boards "to take whatever steps might be necessary to convert to a uritary system .....78 In subsequent cases, the Court refers repeatedly to these two theines. ${ }^{79}$

Though it once again declined to instruct the school board to take specific steps, in Green the Court described the range of alternative remedies a school board must consider in order to satisfy its affirmative duty

Supreme Court has not ... announced any set list of the conditions a district court judge must observe in a formerly dual school system before declaring that the system is unitary.").

More recently the Court stated that it would be "a mistake to treat words such as 'dual' and 'unitary' as if they were actually found in the Constitution." Bd. of Educ. v. Dowell, 498 U.S. 237, 245 (1991). In Green, 391 U.S. at 435, the Court enumerated six areas that revealed the existence of a dual system: student assignment, faculty, staff, transportation, extracurricular activities, and facilities. See also Swann v. Charlotte-Mecklenburg Bd. of Educ., 402 U.S. 1, 18 (1971) (citing the latter five factors as "among the most important indicia of a segregated system" independent of student assignment).

The Court has most recently stated that a school district need not achieve unitary status with respect to all six factors simultaneously before a part of the judicial oversight may be lifted; a district court may partially withdraw judicial supervision with respect to those categories in which a school district has achieved compliance. Freeman v. Pitts, 112 S. Ct. 1430, 1445-46 (1992). The Court reversed the requirement formulated by the Eleventh Circuit that a school district must achieve desegregation with respect to all six Green factors at the same time for a period of not less than three years before it can be called unitary. Pitts v. Freeman, 887 F.2d 1438, 1446 \& n.9 (11th Cir. 1989). The Supreme Court also approved consideration of a seventh factor: quality of education. See Freeman, 112 S. Ct. at 1446-47.

76. Green, 391 U.S. at 441. The Court did not invalidate all "freedom of choice" plans; it found that such plans could be of use under some circumstances. "Where it offers real promise of aiding a desegregation program ... there might be no objection to allowing such a device to prove itself in operation." Id. at 440-41. However, if there are reasonable alternatives available which would provide for speedier, more effective desegregation of schools, a "freedom of choice" plan like the plan struck down in Green is unaeceptable.

77. Id. at 442 .

78. Id. at 437-38.

79. See, e.g., United States v. Montgomery County Bd. of Educ., 395 U.S. 225, 235 (1969) (mandating scheduled desegregation of faculty and staff and quoting Green's command to school boards to come forward with a plan that " "promises realistically to work ... now" "); Davis v. Board of Sch. Comm'rs, 402 U.S. 33, 37-38 (1971) (quoting the same statement and holding that all available and practicable techniques for achieving maximum desegregation must be considered); Swann v. Charlotte-Mecklenburg Bd. of Educ., 402 U.S. 1, 13 (1971) (quoting the same statement and holding that when school authorities fail to propose acceptable solutions, the district court has broad power to fashion remedy assuring a unitary school system).

For cases referring to the school board's affirmative duty to take whatever steps are necessary to convert to a unitary system, sec, for example, Swann, 402 U.S. at 15 (Green imposed an affirmative duty on school boards); Alexander v. Holmes County Bd. of Educ., 396 U.S. 19, 20 (1969) (citing Green and explaining that "[u]nder explicit holdings of this Court the obligation of every school district is to terminate dual school systems at once"). 
to end segregation. Noting that thirteen years had elapsed since Brown had been decided, the Court suggested that the availability of "other more promising courses of action" 80 might indicate a lack of good faith on the part of the school board. The Court further declared that the board had a heavy burden to explain its preference for an apparently less effective method, ${ }^{81}$ and ordered the board to formulate a new plan with "real prospects for disinantling the state-imposed dual systein 'at the earhest practicable date." "82 As the Court clarified in a subsequent unanimous decision, the Green opinion contains an "inphicit coinmand . . . that all reasonable methods be available to formulate an effective reinedy." 83 A district court has a duty to weigh a school board's claim of efficacy "in light of any alternatives which may be shown as feasible and more promising in their effectiveness." 84

\section{D. "The Way Must Always Be Left Open for Experimentation."}

In United States v. Montgomery County Board of Education, ${ }^{86}$ the Supreme Court affirmed a district court order requiring substantially the same ratio of white to black faculty members in each school throughout the system. Arguing that these ratios did not impose "rigid or inflexible orders" ${ }^{87}$ on the school board, the Court acknowledged the need to tailor reinedies to the circumstances of each particular case. ${ }^{88}$ Urging creative solutions, the Court declared that in eliminating segregation, "the way must always be left open for experimentation."89

The Supreine Court has done more than sanction creative relnedies. It has also given district courts authority to order school boards to take specific steps to effect desegregation. ${ }^{90}$ In Swann v. CharlotteMecklenburg Board of Education, for exainple, the district court approved the school board's desegregation plan.91 Several years later, the school system reinained substantially segregated. ${ }^{92}$ The district court

80. Green, 391 U.S. at 439.

81. Id.

82. Id.

83. See North Carolina State Bd. of Educ. v. Swann, 402 U.S. 43, 46 (1971) (absolute prohibition against assignment of students by race for the purpose of creating racial balance "contravenes the implicit command of [Green] that all reasonable methods be available to formulate an effective remedy").

84. Green, 391 U.S. at 439 (emphasis added).

85. United States v. Montgomery County Bd. of Educ., 395 U.S. 225, 235 (1969).

86. 395 U.S. 225 (1969).

87. Id. at 234 .

88. Id. at 235 n.6 (citing Green v. County Sch. Bd., 391 U.S. 430, 439 (1968)).

89. Id. at 235.

90. See Swann v. Charlotte-Mecklenburg Bd. of Educ., 402 U.S. 1, 15 (1971) (emphasizing that the holding in Green affords district courts the authority to order school boards to take "whatever steps might be necessary") (quoting Green, 391 U.S. at 437).

91. Swann, 402 U.S. at 7.

92. Id. 
found the school board's further proposals inadequate and adopted the suggestions of an appointed expert who recommended additional remedies, including a substantial increase in the busing of eleinentary schoolchildren. ${ }^{93}$ In affirming the district court's orders, the Court explained that the term "feasible" as used in Green conteinplated workable, effective, and realistic inethods to end desegregation. ${ }^{94}$

Moreover, the Court placed a high burden on the school board to overcoine claims that the degree of desegregation achieved is inadequate. It explained that where a school district's plan conteinplates the continued existence of soine schools that are all or predominantly one-race, the board "ha[s] the burden of showing that such school assignments are genuinely nondiscriminatory." 95 As the Court later explained in Dayton Board of Education v. Brinkman, 96 the school board has a "heavy burden;"97 it inust show that any actions continuing "the effects of [a] dual system serve important and legitimate ends." 98

\section{E. Limiting Factors}

The Court refined its concept of "the greatest possible degree of actual desegregation" in an important case limiting the powers of federal district courts. Milliken v. Bradley ${ }^{99}$ greatly reduced the power of courts to impose interdistrict remedies. In Milliken, the district court found that plans proposed for the desegregation of Detroit would make the system even inore clearly a one-race system; the inner-city school system would be the "black" systein and the suburban schools would becoine the "white" system. ${ }^{100}$ The court therefore adopted a metropohitan busing plan which included fifty-three Detroit suburbs in the desegregation area. ${ }^{101}$

The Supreme Court invalidated the plan, citing the absence of a finding of wrongdoing by the suburban school districts. Holdimg that the scope of any remedy inust be determined by the extent and nature of the constitutional violation, the Court disallowed interdistrict relief where one of the districts is not culpable. Such rehef is appropriate only when the racially discriminatory acts of one district affect an adjacent district or where district lines have been drawn according to race. ${ }^{102}$

Precluded froin implementimg an interdistrict reinedy, the district

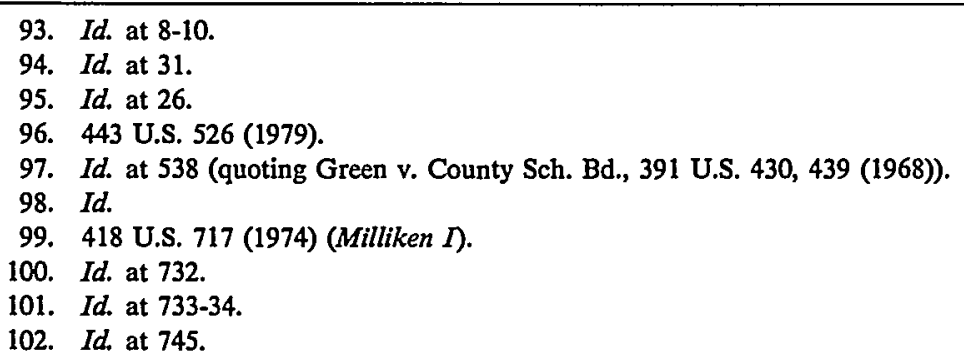


court on remand ordered Michigan to pay a share of the cost of compensatory and remedial programs necessary to correct the effects of past de jure discrimination for which the State had some responsibitity. ${ }^{103}$ The Supreme Court upheld the order. The Court quoted Milliken I, noting that "[t]here are undoubted practical as well as legal limits to the remedial powers of federal courts in school desegregation cases." 104

The contmuing exodus of white students from the KCMSD and the continued refusal of the suburban school districts to accept transfers have left the Jenkins plaintiffs in a situation similar to that of the children of Detroit under Milliken II. There is a crucial difference, however. Milliken II was decided in 1977, when the status of tuition grants under the Estabhishment Clause was, at best, doubtful. In Milliken II, therefore, the "greatest possible degree of actual desegregation"105 may very well have been achieved. In Jenkins, by contrast, one can argue that the greatest possible degree of actual desegregation has not been achieved. Because the status of tuition grants under the Establishment Clause changed considerably after $1977,{ }^{106}$ the practical remedy suggested by the Rivarde plaintiffs is a viable option which remains to be tried.

\section{F. "Prompt" Action: When Court-Ordered Immediate Relief Is Required}

In school desegregation cases, the primary duty to craft a remedy lies with locally elected or appointed school boards. If the school board fails to act promptly, however, the district court has a clearly articulated duty to step in. ${ }^{107}$

In an early Jenkins decision, Judge Clark recognized the court's duty to interfere if necessary: "[T]his Court not only has the power but the duty to enter a decree which will correct the continuing effects of past discrimination as well as bar discrimination against blacks in the

103. Milliken v. Bradley, 433 U.S. 267, 277 (1977) (Milliken In).

104. Milliken II, 433 U.S. at 281 n.15 (quoting Milliken I, 418 U.S. at 763). A school board may not use this language to avoid its affirmative duty, however. See Dayton Bd. of Educ. v. Brinkman, 443 U.S. 526, 538 (1979) (a school board has a heavy burden of showing that actions that continue the effects of the dual system serve important and legitimate ends; a board has to do more than abandon its prior discriminatory purpose; a board has an "affirmative responsibility" to sec that policies and practices do not serve to re-establish a dual school system); Columbus Bd. of Educ. v. Penick, 443 U.S. 449, 460 (1979) ("[W] school' simply by reference to the racial coniposition of teachers and staff, the quality of school buildings and equipment, or the organization of sports activities, a prima facie case . . . under thc Equal Protection Clause is shown.") (quoting Swann v. Charlotte-Mecklenburg Bd. of Educ., 402 U.S. 1,18 (1971)) .

105. Swann, 402 U.S. at 26.

106. See infra notes $158-81$ and accompanying text.

107. Green v. County Sch. Bd., 391 U.S. 430,439 (1968) ("It is incumbent upon the district court to weigh [school board claims about the effeetiveness of its proposed plan for reducing stateinposed segregation] in light of the facts at hand and in light of any alternatives which may bc shown as feasible and more promising in their effectiveness."). 
future."108 But when does the Jenkins court's duty arise? Thirty-nine years have passed since Brown outlawed segregation; sixteen years have passed since Jenkins was originally filed; eight years have passed since the court approved the desegregation plan.

The Supreine Court has never explicitly defined "promptly." In Griffin v. County School Board, ${ }^{109}$ however, the Court found that an eight-year delay was too long, after a court of appeals ordered the district court to take immediate steps toward admitting students without regard to race. ${ }^{110}$ Citing "the inordinate delays which have already occurred in this protracted litigation," 111 the court agreed with the district court that the petitioners were entitled to "quick and effective" rehief ${ }^{12}$ to assure "these petitioners that their constitutional rights will no longer be denied thein."113

When Board of Education v. Dowell ${ }^{114}$ was heard in the court of appeals, ten years had passed since the school board had pledged to abide by the Brown decision. The plaintiffs had brought a class action against the school board to require the board to implenent its (at that time) sixyear-old resolution to coinply with Brown. Noting that the board had "followed a course of integration as slowly as possible," court ordered the school board to include specific procedures in its broad plan of desegregation. The appellate court justified the trial court's soniewhat unusual exercise of power, explaining that although "generally, the power of a court of equity does not extend to the proinulgation of rules or regulations to be adopted and followed by [school] boards,"116 it had "no hesitancy" in sustaining the trial court's authority. ${ }^{117}$

In Green, the Court indicated that even three years inay be too long to wait, where the "first step [toward desegregation] did not come until soine 11 years after Brown $I$ was decided and 10 years after Brown II directed the inaking of a 'pronipt and reasonable start.' "118 The Court explained how to evaluate when a court should intervene in a school district's plan. A plan provides effective rehief only when the district court finds the "plan to have real prospects for disinantling the state

108. Jenkins v. Missouri, 593 F. Supp. 1485, 1505 (W.D. Mo. 1984) (citing Louisiana v. United States, 380 U.S. 145, 154 (1965)).

109. 377 U.S. 218 (1964).

110. Id. at $222-24$.

111. Id. at 226 (quoting Griffin v. Board of Supervisors, 322 F.2d 332, 344 (4th Cir. 1963)).

112. Id. at 232 .

113. Id. at 234 (emphasis added).

114. 375 F.2d 158 (10th Cir. 1967), cert. denied, 387 U.S. 931 (1967).

115. Dowell v. School Bd., 219 F. Supp. 427, 447 (W.D. Okla. 1963) (emphasis added) (later proceedings reported in Board of Educ. v. Dowell, 244 F. Supp. 971 (W.D. Okla. 1965), aff'd, 375 F.2d 158 (10th Cir. 1967), cert. denied, 387 U.S. 931 (1967)).

116. Dowell, 375 F.2d at 165 .

117. Id. at 166 .

118. Green v. County Sch. Bd., 391 U.S. 430, 438 (1968). 
imposed dual system 'at the earliest practicable date." "119 If the plan fails to undo segregation, however, "other means must be used to achieve this end." 120

Similarly, the Court found that three years was too long to wait in Monroe v. Board of Commissioners. ${ }^{121}$ There, the school board's plan for new attendance zones "[p]lainly" did not meet the board's "affirmative duty" to eliminate racial discrimination "root and branch."122 The Court therefore required the school board to formulate a new plan, and "im hight of other courses which appear open to the Board, ... [to] fashion steps which promise realistically to convert promptly to a system without a 'white' school and a 'Negro' school, but just schools."'123

\section{G. The Need for Immediate and Effective Relief in Kansas City}

The Rivarde plaintiffs argue that the current plan has not been effective: in the eight years since it was miplemented, the KCMSD has not achieved unitary status. Most members of the Jenkins class and the Rivarde sub-class are still not receiving a desegregated education. ${ }^{124}$ And it is unlikely that the required standard of desegregation will ever be met under the current plan. ${ }^{125}$ The continuing violation of the plaintiffs' constitutional rights, their urgent need to enroll in desegregated schools at the earliest possible time, and the immediate availability of a feasible remedy demand court action.

The Fourteenth Amendment requires "the greatest possible degree of actual desegregation."126 Such actual desegregation must be implemented with a "feasible" plan "that promises realistically to work . . . now." 127 The Rivarde proponents argue that the remedy they suggest is such a plan. The Rivarde remedy is within the scope of the court's broad equitable power to order desegregation remedies that are "reasonable," "feasible" and "workable." 128 Where difficult probleins require creative

119. Id. at 439 (emphasis added).

120. Id. at 440 (quoting Bowman v. County Sch. Bd., 382 F.2d 326, 333 (4th Cir. 1967) (Sobeloff, J., concurring)).

121. 391 U.S. 450, 456-58 (1968). Three years had elapsed since the district court's approval of new attendance zones.

122. Id. at 458 (quoting Green, 391 U.S. at 437-38).

123. Id. at 459-60 (quoting Green, 391 U.S. at 442).

124. Appellant's Brief at 13, Rivarde v. Missouri, 930 F.2d 641 (8th Cir. 1991) (No. 90-1249).

125. Id. at 14 (noting that a voluntary transfer program cannot succeed without the participation of schools outside the school district, most of whom remain unwilling to accept transfers).

126. See supra notes 61-62.

127. Green, 391 U.S. at 439.

128. See Swann v. Charlotte-Mecklenburg Bd. of Educ., 402 U.S. 1, 31 (1971) ("In Green ... this Court used the term 'feasible' and by implication, 'workable,' 'effective,' and 'realistic' in the mandate to develop 'a plan that promises realistically to work .... .'"). Although the Supreme Court in Green rejected as ineffective a freedom of choice plan involving only public schools, it recognized that "[w]here [a frecdom of choice plan] offers real promise of aiding a desegregation 
remedies, "experimentation" should be welcome. ${ }^{129}$

II

Ordering a Voucher Program in Kansas City:

FEASIBILITY AND Potential ADDITIONAL BENEFITS

The Rivarde proponents need to convince the court that their plan is "feasible." In considering the desirability of a voucher program in Kansas City, the court inay look to the track record of similar programs in other urban settings. While no two cities' experiences are identical, good evidence exists that the Rivarde plan is feasible. Moreover, a brief examination of just two educational experiments-one in Milwaukee, the other in Harlem-suggests that the program might accrue unexpected additional benefits.

\section{A. The Milwaukee Parental Choice Program}

The Rivarde proposal follows the structure of Milwaukee's legislatively-implemented educational choice program-the first of its kind in the nation. The success of the Milwaukee program supports the argument that the Rivarde proposal is administratively feasible.

The Milwaukee Parental Choice Program ${ }^{130}$ enables a limited number of children from low-income families to attend private, nonsectarian schools. ${ }^{131}$ Up to $\$ 2500$ tuition per child is provided by the state, and transportation is provided by the city school system. ${ }^{132}$ Supporters of the Milwaukee Program expect it to save money for the State of Wisconsin, which currently spends $\$ 3500$ to $\$ 5000$ annually to educate each child in the public schools. ${ }^{133}$

Althougl the mam focus of the Milwaukee Program is not desegregation-indeed, it was miplemented in an attempt to remedy the per-

program to effectuate conversion of a state-imposed dual system to a unitary, nonracial system there might be no objection to allowing such a device to prove itself in operation." Green, 391 U.S. at 440 41.

129. United States v. Montgomery County Bd. of Educ., 395 U.S. 225, 235 (1969).

130. W1s. Srat. $\$ 119.23$ (1991). The Wisconsin Supreme Court has upheld the program, reversing an appellate court decision finding that it was enacted contrary to the procedural requirements of the Wisconsin Constitution. Davis v. Grover, 480 N.W.2d 460 (Wis. 1992).

131. William Celis III, State Plan for Choice of Schools Is Voided, N.Y. TIMES, Nov. 14, 1990, at B8.

132. David Nicholson, Schools in Transition, WASH. Post, Aug. 5, 1990, Education Review at 1, 12. The statute requires the state to pay private schools the same amount per pupil as it pays local school districts. WIS. STAT. $\$ 119.23(4)$ (1991). That amount is approximately $\$ 2500$ per child. Nicholson, supra at 12.

133. Kevin Johnson, Private School Aid Put to Test, USA Today, Sept. 6, 1990, at 3A. Of course, the remedy will only save money if the district is able to and does reduce its staff and other costs in proportion to the number of children who choose to leave the public school system. 
ceived negative results of Milwaukee's desegregation plan ${ }^{134}$-it was motivated by many of the same concerns that drive the proponents of the Rivarde plan. In both cities, narrow pursuit of the goal of numerical desegregation had led to the exclusion of many minority children from the most desirable schools. Milwaukee's court-ordered desegregation plan, like the plan currently in effect in Kansas City, expected magnet schools and other inducements to draw black and white students into integrated settings. ${ }^{135}$ However, since inmority students comprised $70 \%$ of the school population in Milwaukee, they were "necessarily excluded froin the most desirable schools so that racial balance could be inaintained."136 It has been suggested that Milwaukee's desegregation plan merely replaced racial segregation with economic-class segregation. ${ }^{137}$ And there was hittle the court could do to remedy econoinic-class segregation in Milwaukee, for there is no constitutional right to a quality education. ${ }^{138}$

The Milwaukee Program was enacted by the Wisconsin Legislature after a 1989 report by the Wisconsin Pohicy Research Institute concluded that Milwaukee's court-ordered desegregation plan had failed to improve the academic performance of black children during its fourteen-year run. ${ }^{139}$ The Milwaukee Parental Choice Program gives low-incoine children access to what parents perceive as a higher quality education outside the public school systein. ${ }^{140}$ Although it is probably too early to analyze the efficacy of the two-year-old plan in improving student performance, ${ }^{141}$ it enjoys the enthusiastic support of many black parents, elected officials of both parties, and community leaders. ${ }^{142}$

134. Don Wycliff, Right to Choose Schools Gains in Debate on Bias, N.Y. T1MEs, June 10, 1990, $\S 1$, at 28 .

135. Id. Funds are scarce in Milwaukee, which spends more than $\$ 50$ million a year on courtordered school busing. MacNeil/Lehrer NewsHour: Competitive Schools (PBS television broadcast, June 18, 1990) (transcript \#3756). From 1976 to 1989, Milwaukee spent $\$ 335$ million on busing, special programs and "incentives" to suburban districts. Nicholson, supra note 132, at 17 (citing a June 1989 report from the Wisconsin Policy Research Institute).

136. Wycliff, supra note 134, at 28 .

137. Nicholson, supra note 132, at 17.

138. Although courts have traditionally focused on numerical desegregation, see supra note 62 , and have never really addressed the issue of quality except in scattered dicta, an argument can be made that the "increased educational opportunity" contemplated by Brown refers to the quality of education. See Freeman v. Pitts, 112 S. Ct. 1430, 1452 (1992) (Scalia, J., concurring).

139. Nicholson, supra note 132, at 17. The study found that in the 1987-88 school year, "black students in Milwaukee's 10 predominantly black high schools failed from 26 to 43 percent of their courses," compared to $24 \%$ for KCMSD public high school students as a group. Id.

For a detailed description of Milwaukee's efforts at desegregation, see David A. Bennett, A Plan for Increasing Educational Opportunities and Improving Racial Balance in Milwaukee, in SCHOOL Desegregation Plans That Work 81 (Charles V. Willie ed., 1984).

140. See Nicholson, supra note 132, at 12.

141. See Department of Polmical Science \& Robert la Follette Inst. of Pub. affairs, Second Year Report, Milwaukee Parental Choíce Program (1 Dec. 1992).

142. Id. at 18-19; see also Teachers vs. Kids, WALL ST. J., June 6, 1990, at A16. National 
Like the Rivarde plan, the Milwaukee plan faced and continues to face strong opposition from the "Education Establishment."143 Although opponents of both plans formally focus on constitutional considerations, it is apparent that political and personal concerns underhe their legal arguments. ${ }^{144}$

There are two basic differences between the Milwaukee Program and the Rivarde plan. The Milwaukee plan was legislatively enacted, in an atteinpt to solve quality-of-education problems that persisted after Milwaukee's public scliools achieved numerical desegregation, ${ }^{145}$ while the Rivarde plan would be court-ordered, in an atteinpt to effect desegregation. The second difference is that in Milwaukee, only non-sectarian schools inay participate in the voucher program. The Rivarde plan, by contrast, would allow parochial scliools to participate. The Rivarde plan thus needs to overcoine concerns that it may violate the Establishment Clause. It seeins clear, however, that the Rivarde plan will help to effect desegregation. ${ }^{146}$ Whether it will increase educational quality at the same time, as parents lope, remains to be seen.

\section{B. Improving Performance: Success in East Harlem}

A successful school choice program in East Harlein lends further support to the feasibility argument by effectively refuting allegations that disadvantaged parents are incapable of making informed cloices about their children's education. The East Harlein prograin also demonstrates the additional benefits that can materialize when parents are given a voice in decisions affecting their children's education.

Although desegregation is the constitutional aim of the Rivarde pro-

statistics show that some sort of educational choice is favored by $72 \%$ of minorities and $62 \%$ of Americans in general. John Leo, School Reform's Best Choice, U.S. NEws \& WoRLD REP., Jan. 14, 1991, at 17.

143. See Mikel Holt, Civil Rights Center Enters Parental Choice Suit, MiLwaukeE CommunITY J., June 6, 1990, at 1, 13 ("[T] he real parties are the (public school) teacher's unions, which fear this program will be successful . ...") (quoting Clint Bolick, Director of Landmark Legal Foundation Center for Civil Rights); The Polly Williams Backlash, WALL ST. J., June 14, 1990, at A14.

144. See, eg., Blocking the Schoolhouse Door, WALL ST. J., June 27, 1990, at A12 ("The Williams plan is a tactical end-run around the public education monopoly's Maginot Liue."); Holt, supra note 143, at 1, 13 ("Clearly, the rcal parties are the (public school) teacher's unions .... They (plaintiffs) know it will (provide low-income youngsters with better educations) and in the process will make public schools look bad by comparison.") (quoting Clint Bolick, Director of Landmark Legal Foundation Center for Civil Rights); Nicholson, supra note 132, at 12; The Polly Williams Backlash, supra note 143, at A14 ("[T]ransfers would so expose the poor job the public schools are doing that their entire budgets would be called into question. That is the real threat that Mrs. Williams poses to the establishment and its status quo."); Teachers vs. Kids, supra note 142, at A16 ("The time has come to ask just whose side the teachers' unions, school bureaucrats and some civil rights groups are on: their own or the kids who endure the dismal state of education in so many parts of this country? In Wisconsin, the answer is becoming very clear.").

145. See Nicholson, supra note 132, at 4; see also Wycliff, supra note 134, at 28.

146. See supra text accompanying notes 9-16. 
gram, proponents of the plan expect an added benefit: they believe that the program will improve the overall quality of education in Kansas City. Although there is little statistical data supporting this argument, one can point to the success of a choice program which began in 1974 in one of the nation's most disadvantaged areas-East Harlem, New York. ${ }^{147}$ If a parental choice plan can improve academic performance in East Harlem, proponents of the Rivarde plan argue, it can do so in Kansas City. ${ }^{148}$

In 1973 there were thirty-two school districts in New York City. The schools in East Harlem ranked last in reading and mathematics. ${ }^{149}$ According to the New York City Board of Education's Pupil Education Report, fewer than $16 \%$ of the students were reading at or above grade level. ${ }^{150}$ In sliort, the district "had nowhere to go but upwards."151 Sy Fliegel, the first director of the alternative school network, understood that "[a] failing system allows for innovation and risk-taking that a mildly successful system miglit not allow."152

In 1974 the district started three small alternative-concept elementary scliools, one of which offered to accept children who were labeled troubleinakers by the regular school system. ${ }^{153}$ Professional staff members at the alternative schools were encouraged to develop new prograins based on their own interests, talents, or philosophical beliefs, and parents were given the power to choose a school geared to their and their children's interests and abilities. ${ }^{154}$

In just seven years, East Harlem raised its district ranking in reading froin 32 nd to 18 th; by 1987 , over $62 \%$ of its students were reading at or above grade level. ${ }^{155}$ The nuinber of graduates adinitted to selective high schools in 1988 was twenty-five tines the number adınitted in $1973 . .^{156}$ Additionally, as of 1982, several hundred white students from outside the

147. Approximately $65 \%$ of the population of East Harlem is Hispanic; the remainder is black. "East Harlem has the eighth highest rate of welfare recipients in the 26 poverty areas of New York City." The percentage of East Harlem residents receiving public assistance is double that of New York City and County as a whole and nearly three times the New York State median. "Twentyseven per cent of the households in the community are headed by single parents." Sy Fliegel, Parental Choice in East Harlem Schools, in PUbLic Schools BY CHOICE: EXPANDING OPPORTUNities for PARENTS, STUdents, AND TEAChers 95, 96 (Joe Nathan ed., 1989).

148. Note, however, that the East Harlem choice program differs from the Rivarde remedy in several respects. The focus of the East Harlem program was to improve education, in contrast to the Rivarde remedy which seeks primarily to end desegregation. Another difference is that the East Harlem program was limited to the public schools. Id. at 96-97.

149. Id. at 96 .

150. Id.

151. Id.

152. Id.

153. Id. at 96-97.

154. Id. at 100 .

155. Id. at 104 .

156. Id. at 105-06. 
predominantly black and Hispanic district voluntarily attended school in East Harlem. ${ }^{157}$

The success of the East Harlem program illustrates the gains that are possible when minority parents are given an opportumity to participate in their children's educations.

\section{III \\ Potential Constitutional Obstacles to Adopting a VOUCHER PROGRAM}

\section{A. The Establishment Clause}

The Estabhishment Clause does not bar the remedy sought by the Rivarde plaintiffs, even though parochial schools are included in the plan. ${ }^{158}$ The Estabhshment Clause allows the expenditure of government funds for an appropriate secular purpose, provided the aid does not result in excessive entanglement between government and religion and flows only indirectly to nonsecular entities. ${ }^{159}$ The Supreme Court has specifically approved the use of government-issued vouchers in nonsecular educational institutions when the voucher programs comply with the above requirements. ${ }^{160}$

The current law has evolved in the twenty years since the Supreme Court articulated its three-part Lemon test for Establishment Clause violations. In Lemon v. Kurtzman, ${ }^{161}$ the Court invalidated a program providing salary supplements to private school teachers. Under the Lemon test, a program is valid if (1) the aid has a secular, as opposed to a religious, purpose; (2) the primary effect of the challenged program does not advance or inhibit religion, and (3) the program does not result in excessive entanglement between government and religion. ${ }^{162}$

Subsequent decisions have produced what one commentator calls "a conceptual disaster area," 163 where it is rarely clear why a particular

157. Id. at 104 .

158. Furthermore, the clause of the Missouri Constitution prohibiting the use of public aid for religious institutions, Mo. CoNST. art. IX, $\S 8$, presents no obstacle because state constitutional limitations cannot prevent relief that is required to desegregate public schools. See North Carolina State Bd. of Educ. v. Swann, 402 U.S. 43, 45 (1971) (state-imposed limitations that obstruct desegregation remedies must fall).

159. See Mueller v. Allen, 463 U.S. 388, 396-402 (1983) (upholding a tax deduction for expenses incurred by parents who provided tuition, textbooks, and transportation for the education of their children).

160. See Witters v. Washington Dep't of Servs. for the Blind, 474 U.S. 481 (1986) (holding that the Establishment Clause does not preclude a state from extending vocational rehabilitation assistance to a blind person studying to be a pastor or a church youth director at a Christian college).

161. 403 U.S. 602 (1971).

162. Id. at $612-13$.

163. Jesse H. Choper, The Establishment Clause and Aid to Parochial Schools-An Update, 75 CALif. L. REv. 5, 6 (1987). 
form of government aid to parochial schools does or does not violate the Establishment Clause.

The Court has held, on the one hand, that government can finance the bus transportation of children to parochial schools but, on the other hand, that government cannot finance the bus transportation for field trips from these parochial schools to cultural and scientific centers ....

The Court has held, on the one hand, that the state can lend state approved secular textbooks to students who attend parochial schools but, on the other hand, that the state cannot lend instructional materials (such as maps, films, movie projectors, or laboratory equipment) either to the students or to the schools .... .

On the question of "auxiliary services," such as remedial courses or guidance counseling, the Court has held, on the one hand, that if a public school teacher enters the parochial school to provide such services, that violates the establishment clause, but, on the other hand, if these same services are offered by these same teachers to these same parochial students outside of the parochial school, it is valid-even if the services are provided in a mobile unit that is parked right at the curb of the parochial school. ${ }^{164}$

The Court has also given conflicting signals regarding tax benefits to parents whose children attend parochial schools. The result is that a "large window for aid to parochial schools" is open and that the issue has simply become a "matter of form."165 In Committee for Public Education \& Religious Liberty v. Nyquist, ${ }^{166}$ for example, the Court mvalidated a New York program that gave partial tuition tax credits only to parents whose children attended private schools. A decade later, in Mueller v. Allen, ${ }^{167}$ the Court distinguished Nyquist in order to uphold a Minnesota tax benefit program providing limited income tax deductions-for actual expenditures incurred for transportation, tuition, and textbooks not used to teach religion - to parents whose children attended either parochial or public schools. The Court noted that the deduction was neutral toward rehigion because it was available to all parents of school-age children. ${ }^{168}$

In applying the Lemon test in Mueller, the Court was reluctant to attribute unconstitutional motives to the states, particularly when a plausible secular purpose could be discerned from the face of the statute. The Court found that the tax deduction had the secular purpose of improving

\footnotetext{
164. Id. at 6-7 (citations omitted).

165. Id. at 11 .

166. 413 U.S. 756 (1973).

167. 463 U.S. 388 (1983).

168. Id. at 397-99.
} 
the education of all children. ${ }^{169}$ Nonpublic scloools were included because they provide a competitive model for the public schools. ${ }^{170} \mathrm{~A}$ secondary secular purpose was also given: private scliools lessen the financial burden on the public school systein; it would cost much inore to educate children in public schools than to give them the relatively nodest subsidy in question. ${ }^{171}$

Under the second part of the Lemon test, the Court found the deduction did not liave the primary effect of advancing the sectarian aims of nonpublic scliools. Ratlier, the statute aided a broad class of beneficiaries, including parents who sent their children to public school. ${ }^{172}$ Furthermore, the aid was given directly to parents and fiowed only indirectly to parochial scliools as a result of nuinerous private clioices of individual parents. ${ }^{173}$ The Court found that " the fact that aid is disbursed to parents ratlier than to ... scliools' is a inaterial consideration in Establishment Clause analysis." 174

Under the third part of the Lemon test, the Court noted that the only plausible source of entanglement arose wliere state officials would have to determine whether particular textbooks would qualify for a deduction. However, such decisions did not inarkedly differ from the types of decisions approved in earlier opinions. ${ }^{175}$

Three years after Mueller, the Supreme Court upheld the constitutionality of a vouclier program in Witters $v$. Washington Department of Services for the Blind. ${ }^{176}$ In Witters, the Court concluded that a state vocational rehabilitation assistance program could be extended to a blind student pursuing a Bible studies degree at a Christian college. The program did not violate the Establishment Clause because its purpose was "unmistakably secular"-the program was designed "to promote the well-being of the visually handicapped tlirough ... vocational rehabilitation services . . .."177 The aid was "in no way skewed towards religion" since any aid that would ultinately flow to religious institutions would do so only as a result of the genuinely independent and private clioices of aid recipients. ${ }^{178}$ Finally, the mere circuunstance that the petitioner chose

169. Id. at 395 .

170. Id.

171. Id.

172. Id. at 397-99.

173. Id. at 399 .

174. Id. at 399 (quoting Committee for Pub. Educ. \& Religious Liberty v. Nyquist, 413 U.S. 756, 781 (1973)). In effect, this "material consideration" means the Court looks at form rather than substance. See Choper, supra note 163, at 11 ("[W] what it may well do in response to Mueller, is amend its invalidated statute to provide the tax credits to parents who send their children to public schools as well.").

175. Mueller, 463 U.S. at 403.

176. 474 U.S. 481 (1986).

177. Id. at $485-86$.

178. Id. at 488 . 
to use neutrally available state aid to help pay for his religious education did not constitute a state endorsement of religion. ${ }^{179}$

As the law stands today, the remedy sought by the Rivarde plaintiffs is consistent with the Establishment Clause. Witters and Mueller indicate that indirect government aid to private institutions based on private choices of parents and students is constitutionally valid. ${ }^{180}$ Under the first prong of the Lemon test, the Rivarde plan serves two separate secular purposes: first, it provides an immediately available remedy to a class of children who have been deprived of their constitutional right to a desegregated education; second, by reducing the concentration of minority students im the overwhelmingly black KCMSD, it will alleviate or at least reduce racial segregation in the district's public schools.

Under the second prong of the Lemon test, the remedy does not advance or inhibit religion, because the state does not influence where individual parents choose to educate their children. Since the proposed assistance would be given directly to individual families, any "assistance" to parochial schools would flow not froin the state but from the individual choices of parents.

Finally, under the third prong of the Lemon test, the program would not result in excessive entanglement between government and religion. The State already inandates mininum standards which all schools-public, private and parochial-must meet. ${ }^{181}$ The receiving schools are already licensed by the state. No additional entanglement would be necessary to inplement this remedy.

\section{B. The Use of Private Institutions to Remedy Racial Segregation}

It is within the Court's remedial power to transfer children to schools outside the KCMSD (including private and parochial schools geographically located within, but not governed by, the KCMSD) provided both the children and the receiving schools volunteer. Indeed, this "voluntary" aspect of the remedy was implicit in the district court's order requiring the KCMSD to pay for transfers to suburban public schools. ${ }^{182}$ Explaining that voluntary transfers could "provide additional

179. Id. at $488-89$.

180. See Choper, supra note 163 , at 13 (explaining that after Witters, "vouchers are now valid but, on the other hand, if aid is provided directly to the schools, it will usually be held invalid").

181. It is difficult to imagine that the state would need to monitor the racial mix of private schools beyond the requirement of present law that such schools not discriminate on the basis of race. See Runyon v. McCrary, 427 U.S. 160 (1976) (private schools that exclude children because of race violate 42 U.S.C. $\S 1981$, which provides that all persons shall have the same right to contract as white persons). The Court did not decide whether a school which offered its services only to an "invited" group would come under the terms of the statute. In addition, it did not expressly decide whether the statute applies to parochial schools that segregate based on religious principles. Id. at 167.

182. Jenkins v. Missouri, 639 F. Supp. 19, 39 (W.D. Mo. 1985), aff'd as modified, 807 F.2d 657 (8th Cir. 1986), cert. denied, 484 U.S. 816 (1987). 
opportunities for desegregated schools as well as desegregative educational experiences for KCMSD students," 183 the court noted that voluntary transfer plans had received encouragement from the Eighth Circuit in similar situations. ${ }^{184}$ In addition, to support its contention that such plans may result im increased desegregation, the court poimted to a successful voluntary transfer plan in St. Louis. ${ }^{185}$

Because the Rivarde remedy includes private schools, it encounters strong opposition from public school administrators and unions. If only public schools were imvolved-if, for example, the suburban public schools were actively soliciting transfers from the KCMSD at no additional cost to the district - the district court's task would be relatively simple. In that case, the court would simply need to balance the competing interests at stake: the constitutional right of black children to a desegregated education, on one side, against a possible loss of income to the KCMSD schools, on the other. Since a transfer program under these circuinstances would advance achievement of the greatest possible degree of actual desegregation, it seens obvious that the children's constitutional right would trump the less compelling economic interests of the school board. The result shonld be the same where some of the providers are private schools. The interests to be balanced remain the same.

The Supreme Court has endorsed a private sector remedy to cure racially segregated housing under circumstances analogous to those in Kansas City. In Hills v. Gautreaux, ${ }^{186}$ the Court upheld a district court order requiring the Chicago Housing Authority to contract for lowincome housing directly with private owners and developers outside of the Chicago city limits to enable some of the Authority's tenants to live in privately-owned suburban housing units. The determination "that a remedy extending beyond the city limits was both 'necessary and equitable' rested in part on the agreement of the parties and the expert witnesses" that a city-only remedy would not work. ${ }^{187}$ The order was allowed to extend beyond city limits provided that it did not unduly coerce local government entities that had not been involved in the discrimination. ${ }^{188}$ If private institutions can help desegregate public housing, they should be able to help desegregate public schools.

183. Id. at 38 .

184. Id. (citing Liddell v. Missouri, 731 F.2d 1294 (8th Cir. 1984) (en banc), cert. denied, 469 U.S. 816 (1984)).

185. Id.

186. 425 U.S. 284 (1976).

187. Id. at 292.

188. Id. at 298. 


\section{Coexistence with the Desegregation Plan Adopted by the Jenkins Court}

Opponents of the Rivarde plan argue that it would require the KCMSD to discard the current desegregation plan. This is simply not the case. The attractiveness of the Rivarde remedy is that it will provide immediate relief to a specific subset of Jenkins plaintiffs who cannot afford to wait until a more comprehensive, long-term plan is implemented. At the same time, it will mcrease the likelihood that the longterm plan will succeed. Judge Clark determined in Jenkins that past segregation and the need to attract and maintain nonmmority enrollment justified a voluntary interdistrict transfer program. ${ }^{189}$ The court of appeals agreed that voluntary transfers were an appropriate choice. ${ }^{190}$ The Rivarde remedy respects that conclusion. It makes voluntary transfers simpler, less expensive, and immediately effective.

By introducing a private sector opportunity, the Rivarde remedy would make the goal of desegregation more achievable, and would allow the district court a chance at accomplishing ${ }^{191}$ what it previously could not. As the Fifth Circuit stated in United States v. Jefferson County Board of Education, "[t]he only school desegregation plan that meets constitutional standards is one that works."192

\section{CONCLUSION}

No one can claim that implementation of a voucher program will solve all of Kansas City's educational problems, much less its racial, economic, and class problems. The least motivated students could, at least in the imitial stages, be left behind. ${ }^{193}$ A potential for some degree of "white flight" from those private schools that participate in the voucher program remains. Such problems-if they arise-will need careful monitoring. But the evidence appears sufficient to justify moving ahead. The

189. Jenkins, 639 F. Supp. at 51 (a voluntary interdistrict transfer program "could provide a significant opportunity for additional desegregation of KCMSD schools as well as desegregative educational experiences for KCMSD students").

190. Jenkins v. Missouri, 807 F.2d 657, 683 n.30 (8th Cir. 1986), cert. denied, 484 U.S. 816 (1987) ("A voluntary interdistrict program is one that has great potential for improving the racial balance in the Kansas City area.").

191. Jenkins, 639 F. Supp. at 45 ("The plan adopted by this Court represents an effort to givc meaning to the constitutional mandate expressed by the Supreme Court thirty years ago, while seeking to be effective in the real world.").

192. United States v. Jefferson County Bd. of Educ., 372 F.2d 836, 847 (1966) (emphasis omitted). "As we see it, the law imposes an absolute duty to desegregate ... [a]nd an absolutc duty to integrate, in the sense that a disproportionate concentration of Negroes in certain schools cannot be ignored; racial mixing of students is a high priority educational goal." Id. at $846-47 \mathrm{n} .5$.

193. The KCMSD has implemented a number of programs to address the needs of its lowest achieving students, and these intervention programs have been successful. The Desegregation Monitoring Committee has recommended increased funding of these programs. See Desegregation Monitoring Comm., supra note 37, at 18-19. 
costs of on-going desegregation programs are staggering in human and economic terms. There is no legal reason to oppose the Rivarde remedy, which at present offers the best available chance of providing a desegregated education for black KCMSD students. Further delay cannot be justified. The Constitution mandates desegregated schools. KCMSD schools remam segregated. Almost forty years after Brown concluded that equality in education is a key to social justice, the children of the KCMSD are still waiting. 
